\title{
Reward processing by the dorsal raphe nucleus: 5-HT and beyond
}

\author{
Minmin Luo, ${ }^{1,2}$ Jingfeng Zhou, ${ }^{1}$ and Zhixiang Liu ${ }^{1}$ \\ ${ }^{1}$ National Institute of Biological Sciences, Beijing 102206, China; ${ }^{2}$ School of Life Sciences, Tsinghua University, Beijing 100084, China
}

\begin{abstract}
The dorsal raphe nucleus (DRN) represents one of the most sensitive reward sites in the brain. However, the exact relationship between DRN neuronal activity and reward signaling has been elusive. In this review, we will summarize anatomical, pharmacological, optogenetics, and electrophysiological studies on the functions and circuit mechanisms of DRN neurons in reward processing. The DRN is commonly associated with serotonin (5-hydroxytryptamine; 5-HT), but this nucleus also contains neurons of the neurotransmitter phenotypes of glutamate, GABA and dopamine. Pharmacological studies indicate that 5-HT might be involved in modulating reward- or punishment-related behaviors. Recent optogenetic stimulations demonstrate that transient activation of DRN neurons produces strong reinforcement signals that are carried out primarily by glutamate. Moreover, activation of DRN 5-HT neurons enhances reward waiting. Electrophysiological recordings reveal that the activity of DRN neurons exhibits diverse behavioral correlates in reward-related tasks. Studies so far thus demonstrate the strong power of DRN neurons in reward signaling and at the same time invite additional efforts to dissect the roles and mechanisms of different DRN neuron types in various processes of reward-related behaviors.
\end{abstract}

Natural rewards such as food, water, sex, and social interaction are critical resources for animals to survive and reproduce. Rewards generate hedonia impacts, motivate behaviors, and direct learning (Berridge et al. 2009). In a changing environment, animals need to constantly adapt their behaviors to obtain rewards. Psychiatric disorders such as major depression and schizophrenia often manifest the symptoms related to deficits in reward processing, such as the failure to experience pleasure and a reduction in motivation (Der-Avakian and Markou 2012).

Since the initial demonstration by Olds and Milner using the approach of electrical intracranial self-stimulation (ICSS) in rats (Olds and Milner 1954), numerous studies have identified the so-called brain reward system-a set of discrete brain structures that are important for processing reward signals. Within the reward system, dopamine neurons in the midbrain ventral tegmental area (VTA) play crucial roles (Schultz et al. 1997; Dayan and Balleine 2002; Cohen et al. 2012; Lammel et al. 2012). The VTA forms strong reciprocal connections with several brain areas, such as the nucleus accumbens (NAc), lateral hypothalamus, and prefrontal cortex (Calabresi et al. 2007). These areas are also considered important stations in the reward system.

Early mapping with electrical ICSS provides the initial hint that the dorsal raphe nucleus (DRN) in the midbrain might be a reward hot spot (Simon et al. 1976; Van Der Kooy et al. 1978; Corbett and Wise 1979; Rompre and Miliaressis 1985). Consistent with this finding, the DRN forms rich interconnections with many stations in the reward system (Peyron et al. 1998; Dorocic et al. 2014; Ogawa et al. 2014; Weissbourd et al. 2014). The DRN is best known as the origin of extensive serotonergic projections to the forebrain. The brain serotonergic system has attracted particular interests because the 5-HT signaling pathway has been successfully targeted to treat depression, schizophrenia, and general anxiety (Owens and Nemeroff 1994; Hirschfeld 2000). The involvement of the 5-HT in reward processing has been extensively demonstrated by studies using diverse approach-

Corresponding author: luomm@tsinghua.edu.cn Article is online at http://www.learnmem.org/cgi/doi/10.1101/Im.037317.114. es, including lesion, pharmacological manipulations, genetics, electrophysiological recordings, and behavioral assays. However, data from different experiments often lead to seemingly contradictory views on the exact functions of 5-HT or DRN neurons as a whole. It has been theorized that 5-HT mediates the behavioral responses to aversive stimuli (punishment) by antagonizing the action of dopamine (Soubrie et al. 1986; Deakin and Graeff 1991; Daw and Touretzky 2002; Dayan and Huys 2009). Moreover, 5-HT may track long-term reward states at slow time scales (minutes to hours) and modulate mood (Daw et al. 2002; Savitz et al. 2009). Finally, 5-HT may mediate behavioral inhibition and promote animal patience while waiting for reward (Soubrie et al. 1986; Miyazaki et al. 2011a,b). These earlier data and theories have been summarized by several excellent reviews (Dayan and Huys 2009; Kranz et al. 2010; Hayes and Greenshaw 2011; Miyazaki et al. 2012a; Nakamura 2013).

The DRN also contains a substantial number of nonserotonergic neurons and 5-HT can also be released by neurons outside the DRN, suggesting the difficulty in accurately inferring dorsal raphe functions by investigating the effects of 5-HT alone. Through directly manipulating or recording the activity of DRN neurons, a number of studies recently provided some exciting new insights into the functions of these neurons in reward signaling. In this review, we will focus on more recent studies on this topic and discuss their functional implications as well as important future experiments.

\section{Cell types and anatomical connectivity of the DRN}

As a highly conserved brain structure in vertebrates, the DRN is a sector-shaped nucleus located ventral to the midbrain aqueduct.

(C) 2015 Luo et al. This article is distributed exclusively by Cold Spring Harbor Laboratory Press for the first 12 months after the full-issue publication date (see http://learnmem.cshlp.org/site/misc/terms.xhtml). After 12 months, it is available under a Creative Commons License (Attribution-NonCommercial 4.0 International), as described at http://creativecommons.org/licenses/by$\mathrm{nc} / 4.0 /$. 
It comprises the largest population of 5-HT neurons ( $~ 9000$ in mice) (Ishimura et al. 1988). 5-HT neurons consist of up to twothirds of total neurons in the DRN and provide $\sim 70 \%$ of 5 -HT in the forebrain (Hökfelt et al. 2000; Commons 2009; Fu et al. 2010; Hioki et al. 2010). Neurons expressing the 5-HT markers of tryptophan hydroxylase 2 (Tph2) and serotonin transporter (SERT) are located in the midline area and the two lateral wings of the DRN (Fig. 1A). These neurons release 5-HT throughout the brain to trigger a wide range of signaling pathways via at least 14 receptors in mammals (Green 2006; Hayes and Greenshaw 2011; Lesch and Waider 2012). DRN 5-HT neurons are heterogeneous in cell morphology, neurochemical markers, projection preferences, function topography, and electrophysiological properties (Abrams et al. 2004; Calizo et al. 2011; Bang et al. 2012). Recently, three independent groups mapped the whole-brain inputs to the DRN 5-HT neurons using the transsynaptic tracing method based on modified rabies virus (Dorocic et al. 2014; Ogawa et al. 2014; Weissbourd et al. 2014). Similar to VTA dopamine neurons (Ogawa et al. 2014), DRN 5-HT neurons receive broad and dense inputs from a broad range of forebrain and limbic structures that are tightly involved in reward processing and emotion control (Fig. 1B; Dorocic et al. 2014; Ogawa et al. 2014; Weissbourd et al. 2014).

In addition to 5-HT, glutamate is released by many DRN projection neurons. Many DRN neurons express the vesicular glutamate transporter 3 (VGluT3) but not VGluT1 and VGluT2 (Fremeau et al. 2002; Gras et al. 2002; Schäfer et al. 2002; Herzog et al. 2004). VGluT3 is found in approximately two-thirds of 5-HT neurons, especially those located along the midline (Fig. 1A; Hioki et al. 2010). A subset of VGluT3+ neurons within the shell region of the DRN dorsal part (DRD shell) is nonserotonergic, whereas most 5-HT neurons in the two lateral wings lack VGluT3 expression (Hioki et al. 2010; Liu et al. 2014). Whole-cell recordings from brain slices demonstrate that DRN neurons release glutamate in a VGluT3-dependent manner (Liu et al. 2014; Qi et al. 2014). VGluT3+ serotonergic fibers are present in the cerebral cortex, lateral septum (Shutoh et al. 2008), VTA (Qi et al. 2014), hippocampus (Jackson et al. 2009), and olfactory bulb (Suzuki et al. 2015), whereas nonserotonergic VGluT3+ fibers mainly target the VTA/substantial nigra compacta (SNc), multiple hypothalamic and thalamic areas, preoptic area, ventral palladium, hippocampus, and medial septum (Jackson et al. 2009; Hioki et al. 2010; Qi et al. 2014). The inputs to DRN VGluT3+ neu- rons are yet to be mapped in the cell-type specific manner using the rabies virus approach.

GABAergic neurons are found mainly in the lateral DRN, with a very small minority coexpressing markers for 5-HT but not glutamate (Hioki et al. 2010). As the major interneurons in the DRN, they express 5-HT2 receptors to receive local serotonergic input and mediate feedback inhibition to 5-HT neurons (Liu et al. 2000). Recent transsynaptic tracings reveal that DRN GABA neurons share a largely similar input pattern with 5-HT neurons (Dorocic et al. 2014; Weissbourd et al. 2014). However, neurons from the central amygdala and the bed nucleus of the stria terminalis preferentially innervate GABAergic neurons, suggesting that these brain areas exert a more powerful modulation of DRN functions through GABAergic interneurons (Weissbourd et al. 2014).

A small fraction of DRN neurons ( 1000 in mice) in the rostral-dorsal part of the DRN expresses the dopamine markers tyrosine hydroxylase and dopamine transporter (DAT) (Flores et al. 2004). These neurons do not express 5-HT markers, indicating that they form a separate neuron population (Stratford and Wirtshafter 1990; Hioki et al. 2010). They resemble VTA dopamine neurons in terms of projection patterns and electrophysiological properties, suggesting that this cell population represents an extension of the A10 dopamine system (Descarries et al. 1986; Yoshida et al. 1989; Stratford and Wirtshafter 1990; Dougalis et al. 2012).

\section{Pharmacological manipulations provide conflicting views}

Initial pharmacological studies provided some exciting but apparently conflicting conclusions on the functions of 5-HT in reward-related behaviors. Many experiments support the theory that 5-HT encodes punishment signals by opposing dopamine actions (Tye et al. 1977; Hashimoto et al. 1996; Daw et al. 2002; Clarke et al. 2004; Di Giovanni et al. 2010; Macoveanu 2014). Altering central 5-HT levels negatively affects reward effects elicited by natural rewarding stimuli (Fletcher et al. 1999; Sanders et al. 2007), addictive drug (Leccese and Lyness 1984; Smith et al. 1986; Carroll et al. 1990; McGregor et al. 1993; Peltier and Schenk 1993), and electrical ICSS (Redgrave 1978; Bauer et al. 2013). Reward inhibition by 5-HT appears to be mainly mediated by
A

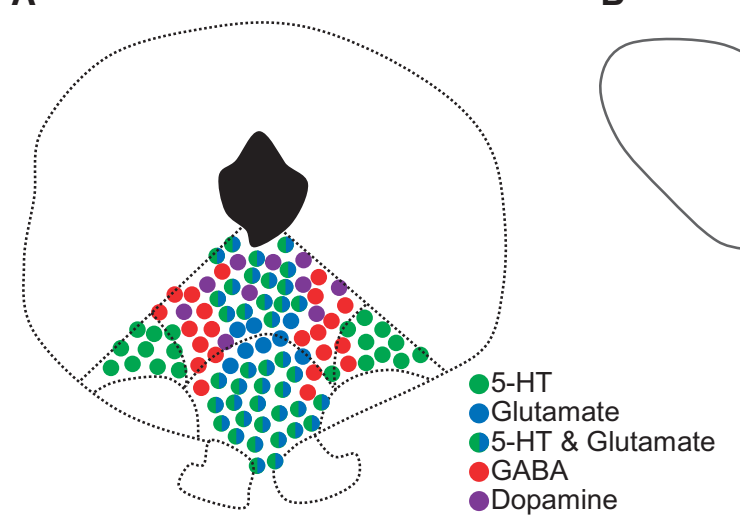

B

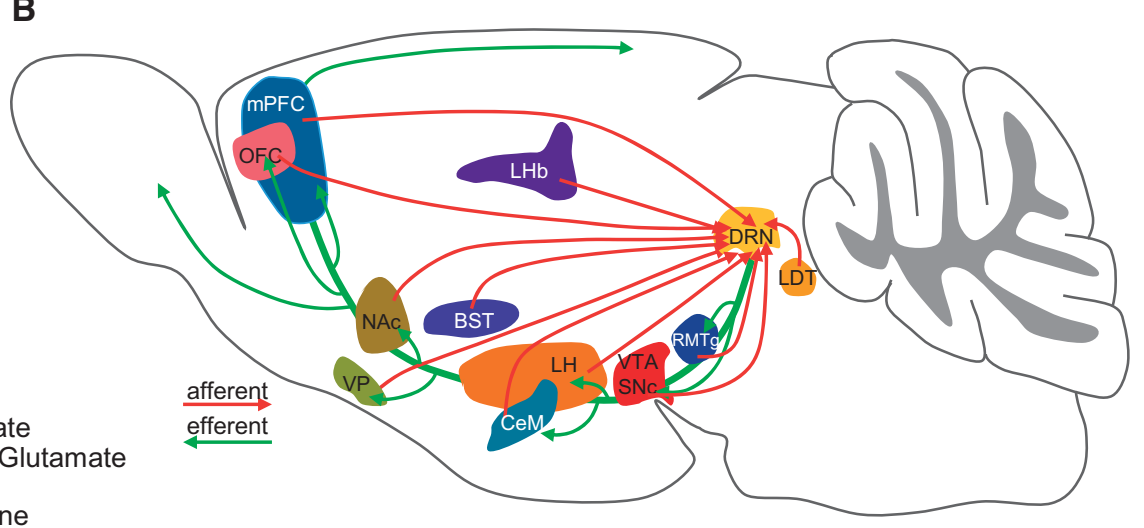

Figure 1. Neuron types in the DRN and the connectivity of 5-HT neurons. ( $A$ ) A cartoon shows the distribution of 5-HT, glutamate, GABA and dopamine neurons in the DRN. Note that some neurons express markers for both 5-HT and glutamate. ( $B$ ) Input and output patterns of DRN 5-HT neurons. (mPFC) medial prefrontal cortex, (OFC) orbitofrontal cortex, (VP) ventral pallidum, (NAc) nucleus Accumbens, (LHb) lateral Habenula, (BST) bed nucleus of the stria terminalis, (CeM) central amygdala, (LH) lateral hypothalamus, (DRN) dorsal raphe nucleus, (VTA) ventral tegmental area, (SNc) substantia nigra pars compacta, (RMTg) rostromedial tegmental nucleus, and (LDT) laterodorsal tegmental nucleus. 
the 5-HT2C receptor (Higgins and Fletcher 2003; Cunningham et al. 2011; Katsidoni et al. 2011). In addition, infusion of 5-HT or 5-HT1B receptor agonists into the NAc decreases amphetamine self-administration (Fletcher et al. 2002) and amphetamineconditioned reward response (Fletcher 1996; Fletcher and Korth 1999). The application of 8-OH-DPAT, a 5-HT1A auto-receptor agonist that mainly inhibits 5-HT neurons and decreases 5-HT levels in the VTA (Chen and Reith 1995), increases the firing of VTA dopamine neurons (Prisco et al. 1994) and elicits conditioned place preference (Fletcher et al. 1993). Finally, intra-DRN infusion of $\mathrm{GABA}_{\mathrm{A}}$ or $\mathrm{GABA}_{\mathrm{B}}$ receptor agonists supports self-administration in rats (Liu and Ikemoto 2007; Shin and Ikemoto 2010), although it is unclear whether activating GABA receptors truly reduces 5-HT release from the DRN (Tao et al. 1996; Abellán et al. 2000). In addition to the direct effects on reward, many other studies find that global 5-HT depletion results in impulsive, fast-responding, and premature behavioral responses, suggesting that the 5-HT signaling system may be important for behavioral inhibition and impulsivity control (Harrison et al. 1997; Winstanley et al. 2004; Miyazaki et al. 2012a).

Although these experiments support the notion that DRN neurons release 5-HT to inhibit natural or drug-induced reward via dopamine antagonism, data from many other studies lead to opposite views. An early study reported that electrical selfstimulation of the medial forebrain bundle is potentiated by 5-HT infusion near the area of dopamine neurons in the ventral midbrain and suggests that 5-HT sensitizes reward (Redgrave and Horrell 1976). MDMA (3, 4-methylenedioxymethamphetamine), a psychoactive drug, creates euphoric surge through massive release of 5-HT (Gartside et al. 1997; Liechti and Vollenweider 2001). Selective serotonin reuptake inhibitors (SSRIs) are commonly used to treat depression by blocking SERT to increase 5-HT levels (Hirschfeld 2000). Diet rich in tryptophan increases serotonin release and induces rewarding effects in rats (Orosco et al. 2004). Local dopamine release is increased following infusion of 5-HT or SSRIs into the rat prefrontal cortex (Matsumoto et al. 1999). Fluoxetine, the most commonly used SSRI, induces conditioned reward response even in dopamine-deficient mice (Sasaki-Adams and Kelley 2001; Hnasko et al. 2007). Depleting 5-HT impairs reward learning and reward processing in human and rodents (Izquierdo et al. 2012; Seymour et al. 2012). Furthermore, 5-HT2C receptors are expressed both in VTA dopamine and GABA neurons (Bubar and Cunningham 2007; Bubar et al. 2011) and exert more complex effects than merely inhibiting VTA dopamine neurons (Minabe et al. 1996, 2001; Blackburn et al. 2002). Finally, cocaine self-administration is sensitized by genetic deletion of 5-HT1B receptor and suppressed by 5-HT receptor agonists, leading to the interpretation that 5-HT enhances drug reward values (Rocha et al. 1998; Przegaliński et al. 2007).

Genetic manipulations also offer a very complex picture. For example, knocking out SERT reduces mouse reward-seeking behaviors (Sanders et al. 2007) but improves reversal learning (Brigman et al. 2010). SERT knockout rats are unable to change behaviors based on expected reward values in a Pavlovian reinforcer devaluation paradigm (Nonkes et al. 2010), and respond excessively to the conditioned stimuli in an operant conditioning task (Nonkes and Homberg 2013). Knocking out Tph2 results in impulsivity, hyper-aggression, and abnormal sociosexual behaviors (Savelieva et al. 2008; Liu et al. 2011; Angoa-Perez et al. 2012; Kane et al. 2012; Zhang et al. 2013; Gutknecht et al. 2015).

How to reconcile these different and often opposite findings? Some of the conflicts may be produced by the difference in drugs, their delivery approaches (systemic versus local infusion), targeted brain areas, and dosages (high versus low). Although pharmacological studies produce many interesting insights into the functions of the 5-HT signaling pathway, it is difficult to precisely link the drug effects to the activity of DRN 5-HT neurons. Drug infusion tends to be slow and diffusive. Moreover, application of a specific receptor agonist or antagonist into a given brain area inevitably misses the global picture of how DRN 5-HT neurons modulate or organize behaviors by acting on the full set of 5-HT and glutamate receptors throughout their downstream brain areas (Hayes and Greenshaw 2011). To overcome many of these shortcomings, we need to manipulate (stimulate, inhibit, and ablate) dorsal raphe neurons in a cell-type-specific and temporally precise manner. In addition, we need to understand the activity patterns of different types and subtypes of dorsal raphe neurons while animals perform various reward-associated tasks.

\section{Optogenetics reveal two different roles of DRN neurons in reward processing}

The development of optogenetic tools allows temporally precise manipulation of DRN neuron activity in a cell-type specific manner (Boyden et al. 2005; Fenno et al. 2011). Recently, several groups studied the effect of stimulating various types of DRN neurons on several reward-associated tasks. Table 1 summarizes the targeted cell types, optogenetic tools, behavioral assays, and key findings.

Two main conclusions can be reached from these optogenetic experiments so far. First, activation of DRN neurons strongly drives reward behaviors primarily in a glutamate-dependent manner. Optogenetic suppression of DRN GABA neuron activity disinhibits non-GABA neurons and prevents mice from acquiring social avoidance (Challis et al. 2013), which gives the initial hint that the activity of DRN non-GABA neurons may reduce the aversiveness of social defeat. Our group examined the behavioral effects of optogenetic stimulation of mouse DRN Pet-1 neurons (Liu et al. 2014), which consist of mostly 5-HT neurons ( $\sim 90 \%)$ and some purely glutamate neurons ( $\sim 10 \%)$. Brief stimulations $(2-3 \mathrm{sec})$ support light self-administration, shift sucrose preference, guide olfactory discrimination learning, and rapidly shape the firing pattern of cortical neurons in a closed-loop brain-machine interface (Liu et al. 2014). Moreover, activation of DRN Pet-1 neurons, resembling the natural reward of sucrose, directs the formation of the prospective activation patterns in the orbitofrontal cortex (Zhou et al. 2015). Pet-1 neurons release both 5-HT and glutamate in the VTA and NAc and the glutamate release requires VGluT3 (Liu et al. 2014). Surprisingly, the reward effects are substantially reduced by knocking out VGluT3 but not Tph2 (Fig. 2A), the key enzyme for central 5-HT synthesis (Walther et al. 2003). The residue reward effect in VGluT3 KO mice is abolished by chemical depletion of 5-HT (Liu et al. 2014). Genetic depletion of central 5-HT weakens the reinforcement ability of DRN stimulation when mice are engaged in more challenging tasks, suggesting a role of 5-HT in maintaining high motivation (Fig. 2B; Liu et al. 2014). Thus, stimulation of DRN Pet-1 neurons produces reward signals mainly through glutamate, although 5-HT also plays a role. The contribution of both glutamate and 5-HT in reward signaling may offer a new perspective to understand the paradox role of SSRI on depression (Fischer et al. 2015).

Two other studies report that optogenetic stimulation of DRN neurons drives reward behavior and emphasizes the contribution of glutamate (McDevitt et al. 2014; Qi et al. 2014). McDevitt et al. reported that light self-administration is supported by activating all DRN neurons, but not specific subpopulations of 5-HT, dopamine, or GABA neurons. The authors further demonstrated that DRN neurons release glutamate in the VTA and suggested the importance of glutamate neurotransmission from the DRN to the VTA (McDevitt et al. 2014). Qi et al. (2014) directly examined the physiological and behavioral effects of optogenetic 
Table 1. Recent optogenetic studies that investigate the relationship between the DRN and reward

\begin{tabular}{|c|c|c|c|c|}
\hline Key findings & Behavioral tests & Mouse strains (cell type) & Tools & Studies \\
\hline $\begin{array}{l}\text { Suppression of GABA neurons } \\
\text { enhances the activity of 5-HT } \\
\text { neurons and prevents the } \\
\text { acquisition of social avoidance. }\end{array}$ & Social interaction & $\begin{array}{l}\text { GAD2-Cre (Taniguchi et al. } \\
\text { 2011) } \\
\text { (GABA cells) }\end{array}$ & AAV-DFI-Arch & $\begin{array}{l}\text { (Challis } \\
\text { et al. } \\
\text { 2013) }\end{array}$ \\
\hline $\begin{array}{l}\text { - Activation of Pet-1 neurons } \\
\text { reinforces behavior and drives fast } \\
\text { behavioral and neural learning. } \\
\text { - Pet-1 neurons are tonically } \\
\text { activated during reward } \\
\text { expectation and consumption. } \\
\text { - Loss of either glutamate or 5-HT } \\
\text { transmission impairs reward } \\
\text { effects. }\end{array}$ & $\begin{array}{l}\text { iClass; Operant light self-stimulation; } \\
\text { Two-bottle preference; Conditioned } \\
\text { place preference; Go/No-go olfactory } \\
\text { learning; Brain-machine interface } \\
\text { task }\end{array}$ & $\begin{array}{l}\text { ePet1-Cre (Scott et al. 2005) } \\
\text { (Pet-1 cells;90\% 5-HT;10\% } \\
\text { glutamate only) } \\
\text { ePet1-Cre } \times \text { Tph2- - - (Pet-1 } \\
\text { cells lacking Tph2) } \\
\text { ePet1-Cre } \times \text { VGluT3- }- \\
\text { (Pet-1 cells lacking VGluT3) }\end{array}$ & AAV-DIO-ChR2 & $\begin{array}{l}\text { (Liu et al. } \\
\text { 2014) }\end{array}$ \\
\hline $\begin{array}{l}\text { Nonserotonergic neurons signal } \\
\text { reward through VTA dopamine } \\
\text { neurons }\end{array}$ & $\begin{array}{l}\text { Real-time place preference; Operant } \\
\text { self-stimulation }\end{array}$ & 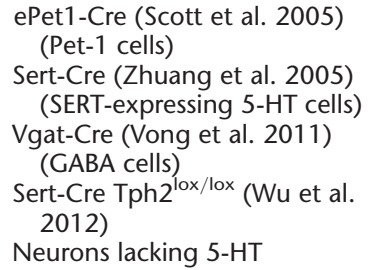 & $\begin{array}{l}\text { Cre ON/OFF } \\
\text { ChR2 }\end{array}$ & $\begin{array}{l}\text { (McDevitt } \\
\text { et al. } \\
\text { 2014) }\end{array}$ \\
\hline $\begin{array}{l}\text { Projection from DRN } \\
\text { VGluT3-expressing neurons to VTA } \\
\text { dopamine neurons mediates } \\
\text { strong reward. }\end{array}$ & $\begin{array}{l}\text { Real-time place preference; Operant } \\
\text { self-stimulation }\end{array}$ & $\begin{array}{l}\text { VGluT3-Cre (Grimes et al. } \\
\text { 2011) } \\
\text { (VGluT3-expressing glutamate } \\
\text { cells) }\end{array}$ & AAV-DIO-ChR2 & $\begin{array}{l}\text { (Qi et al. } \\
\text { 2014) }\end{array}$ \\
\hline $\begin{array}{l}\text { Activation of } 5 \text {-HT neurons enhances } \\
\text { animals' patience but is not } \\
\text { rewarding }\end{array}$ & Sequential tone-food waiting task & $\begin{array}{l}\text { Tph2-ChR2(C128S) (Ohmura } \\
\text { et al. 2014) } \\
\text { (Tph2-expressing 5-HT cells) }\end{array}$ & $\begin{array}{l}\text { transgenic ChR2 } \\
\text { expression }\end{array}$ & $\begin{array}{l}\text { (Miyazaki } \\
\text { et al. } \\
\text { 2014) }\end{array}$ \\
\hline $\begin{array}{l}\text { Orbitofrontal neurons exhibit similar } \\
\text { conditioned responses toward } \\
\text { DRN stimulation and sucrose } \\
\text { solutions. }\end{array}$ & Optogenetic Pavlovian conditioning & $\begin{array}{l}\text { ePet1-Cre (Scott et al. 2005) } \\
\text { (Pet-1 cells) }\end{array}$ & AAV-DIO-ChR2 & $\begin{array}{l}\text { (Zhou et al. } \\
\text { 2015) }\end{array}$ \\
\hline $\begin{array}{l}\text { Activation of 5-HT neurons promotes } \\
\text { patience of animals but does not } \\
\text { reinforce animal behaviors. }\end{array}$ & $\begin{array}{l}\text { Reward waiting task; Light } \\
\text { self-stimulation }\end{array}$ & $\begin{array}{l}\text { SERT-Cre (Gong et al. 2007) } \\
\quad \text { (SERT-expressing 5-HT cells) }\end{array}$ & AAV-DIO-ChR2 & $\begin{array}{l}\text { (Fonseca } \\
\text { et al. } \\
\text { 2015) }\end{array}$ \\
\hline
\end{tabular}

stimulation of VGluT3-expressing neurons in the mouse DRN. Stimulating axonal fibers from VGluT3 + neurons results in glutamate release and activates VTA mesoaccumbens dopamine neurons in brain slices. In addition, optogenetic stimulation of DRN VGluT3 neurons reinforces instrumental behavior and establishes conditioned place preference, suggesting the strong potential of glutamate neurons in reward signaling (Qi et al. 2014).

The second major conclusion arises from two optogenetic studies that demonstrate a significant effect of activating DRN 5-HT neurons on promoting reward waiting (Miyazaki et al. 2014; Fonseca et al. 2015). In both studies, mice were trained to perform a delayed reward task. Optogenetic stimulation of DRN 5-HT neurons increases animal's capacity of waiting for delayed reward delivery (Miyazaki et al. 2014; Fonseca et al. 2015). Furthermore, the patience-promoting effect does not rely on behavioral reinforcement. These interesting observations are consistent with physiological recordings that show activation of putative 5-HT neurons in the rat DRN while animals wait for rewards and conditioned reinforcement tones (Miyazaki et al. 2011a,b). The reward waiting capacity of animals is impaired by inhibiting 5-HT neurons with pharmacological and optogenetic methods (Miyazaki et al. 2012b, 2014). Although the underlying neurotransmitter remains to be probed, this series of studies strongly indicates that the activity of DRN 5-HT neurons serves to bridge delays to future rewards and reward-related stimuli (Miyazaki et al. 2012a).

Additional experiments are required to clarify why mouse behaviors are strongly reinforced by stimulation of Pet- 1 neurons but not 5-HT neurons marked with SERT or Tph2 (Liu et al. 2014; McDevitt et al. 2014; Miyazaki et al. 2014; Fonseca et al.
2015). One possibility lies in the choice of mouse lines. Although the ePet1-Cre mouse line labels $>95 \%$ of the DRN TPH $2^{+}$neurons in adult mice (Scott et al. 2005; Liu et al. 2014), a subpopulation of 5-HT neurons does not express Pet-1 gene (Kiyasova et al. 2011). Furthermore, Pet-1 neurons consist of both 5-HT neurons (90\%) and glutamate neurons (10\%). The discrepancy might be
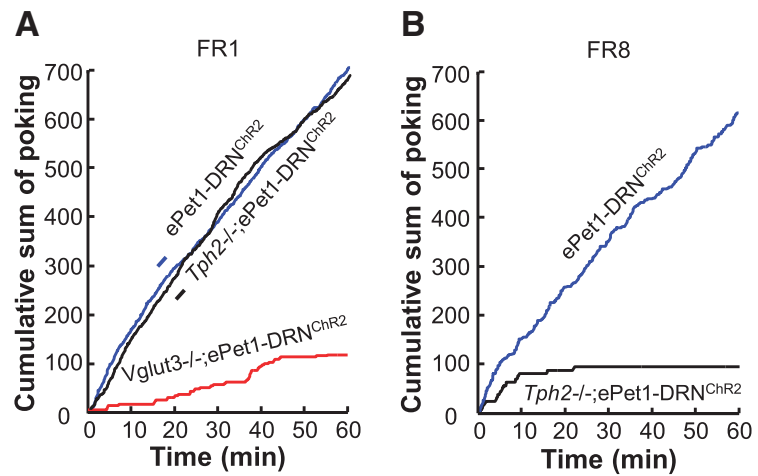

Figure 2. Both glutamate and 5-HT contribute to reward signaling of DRN Pet-1 neurons. (A) Plots of cumulative active nose-pokes of mice showing that optogenetic stimulation of DRN Pet-1 neurons supports strong self-administration of light involving a fixed ratio 1:1 (FR1) schedule. Deleting the gene encoding VGluT3 but not Tph2 substantially reduces the effectiveness of light stimulation. (B) Genetic deletion of Tph2 drastically reduces animal performance in a test involving FR8 schedule, which requires mice making eight active pokes to receive light delivery into the DRN. Adopted from Liu et al. 2014 with permission. 
additionally produced by differences in optogenetic tools, labeling efficiency, stimulation parameters (intensity and duration), and behavioral tests (Table 1). For example, we used brief stimulation of DRN Pet-1 neurons (Liu et al. 2014), whereas other studies used slightly longer and weaker stimulation of Tph2-expressing or SERT-expressing neurons (Miyazaki et al. 2014; Fonseca et al. 2015).

Regardless the exact technical reasons, the optogenetic studies raise an important question on the exact contribution of glutamate and 5-HT to the reinforcement and reward waiting potentials of DRN neurons. It has been proposed that the rewarding effect of DRN stimulation is mediated by the glutamate transmission from the DRN to the VTA (McDevitt et al. 2014; Miyazaki et al. 2014; Qi et al. 2014; Ranade et al. 2014; Fonseca et al. 2015; McDannald 2015). However, several lines of evidences suggest that this interpretation might be overly simplified. Although knocking out VGluT3 substantially reduces the potential of behavioral reinforcement induced by stimulating Pet-1 neurons, stimulation of VGluT3-/ - Pet-1 neurons can condition animal place preference and counter the innate sucrose preference at the level of 1\% sucrose (Liu et al. 2014). More important, the residue rewarding effects is abolished by chemical depletion of 5-HT (Liu et al. 2014). There also exists substantial overlap between 5-HT neurons and glutamate neurons in the DRN (Hioki et al. 2010; Liu et al. 2014; Qi et al. 2014), including neurons projecting to the VTA (Liu et al. 2014; Qi et al. 2014). Finally, several genetic studies show that the 5-HT signaling pathway contributes to drug reward in a dopamine-independent manner. Although it is commonly believed that the dopamine transporter DAT is crucial for cocaine reward, knocking out DAT does not completely disrupt cocaine reward (Sora et al. 1998), whereas additional knockout of SERT does (Sora et al. 2001). Moreover, fluoxetine and cocaine produces conditioned place preference in the dopamine-deficient mice, suggesting that 5-HT is involved in mediating the cocaine reward (Hnasko et al. 2007).

\section{Imaging and recordings reveal activation of DRN neurons in reward tasks}

Understanding the DRN functions requires the knowledge of activity patterns of DRN neurons, ideally from animals and humans performing reward-related tasks. The fMRI method provides a powerful tool to correlate the DRN neural activity with reward signals, particularly in humans and nonhuman primates. Tanaka et al. (2004) showed that the DRN is activated prior to a large future gain together with a small immediate loss in human subjects. The recreational drug MDMA strongly activates the DRN in awake monkeys (Brevard et al. 2006). Other fMRI imagings report DRN activation by social behaviors and social signals (Ferris et al. 2004; Acevedo et al. 2012). However, the neural responses of the DRN are negatively covaried with the responses of the nucleus accumbens to the magnitude of omitted rewards (Pedroni et al. 2011). In addition, global change of 5-HT levels results in mixed response patterns in multiple brain areas, including those in the brain reward system (Macoveanu 2014).

Electrophysiological recordings provide the information of rapid neuronal activity change at the single-cell level. Earlier single-unit recording in behaving animals mainly focused on the association of putative DRN 5-HT neurons with sleep/awake state (McGinty and Harper 1976; Sakai and Crochet 2001) and motor activities (Fornal et al. 1996; Waterhouse et al. 2004). Nakamura et al. (2008) first reported that the spike firing activity of some primate DRN neurons is tonically modulated before and after the delivery of juice reward and faithfully tracks the actual reward values. DRN neurons that encode the positive reward signals tend to be more tonically excited during tasks (Bromberg-Martin et al. 2010). In a multitrial schedule task, the DRN neurons respond differentially to reward sizes, task events, and task progress, and thus may provide a mechanism to mintor task states throughout goal-directed behaviors (Inaba et al. 2013). Recordings from the rat DRN also reveal tonic firing toward delayed rewards or delayed reward-predicting tones (Miyazaki et al. 2011a). The tonic signals of these neurons persist until successful reward/tone delivery or omission errors, suggesting a facilitation of waiting behavior by the DRN neurons. In addition to the tonic firing modes, many rat DRN neurons exhibit transient firing activity that are selectively tuned to sensory cues, motor responses, and reward events in a two-alternative choice behavior (Ranade and Mainen 2009). On the other hand, some recordings find negative correlations of DRN neuronal activity with reward signals. Subsets of DRN neurons are activated or inhibited by intense noxious stimulus in anesthetized rats (Schweimer and Ungless 2010). In a contextual conditioned approach paradigm, DRN neurons are more transiently activated by an auditory cue in a non-reward context than in a reward context ( $\mathrm{Li}$ et al. 2013). Interestingly, single DRN neurons may be transiently activated by appetitive stimuli transiently and slowly modulated by aversive stimuli, suggesting that the DRN may encode both appetitive and aversive information at different time scales (Hayashi et al. 2015).

The diverse behavioral correlates of neuronal activity in the DRN may reflect the substantial heterogeneity in the neurotransmitter phenotypes and functions of DRN neurons. Some extracellular recordings used spike waveform features to identify 5-HT neurons. However, the combination of juxtacellular recording/labeling and immunohistochemistry has shown that this approach can be quite inaccurate (Allers and Sharp 2003; Kirby et al. 2003; Hajós et al. 2007; Schweimer et al. 2011). By identifying recorded cell types with optical tagging, two recent studies examined the activity patterns of putative 5-HT neurons in mice performing a classical conditioning task. A majority of DRN Pet-1 (mostly 5-HT) neurons are tonically activated following reward-predicting cues and during reward consumption in a cue-reward association task (Fig. 3; Liu et al. 2014). Cohen et al. (2015) made the similar observation among SERT-expressing 5-HT neurons. Moreover, the baseline activity of some 5-HT neurons slowly fluctuates across reward/punishment blocks. Surprisingly, a majority of 5-HT neurons fire phasically following air puff to the animal face, although it remains unclear whether this indicates a response to punishment or salient sensory cues (Cohen et al. 2015).

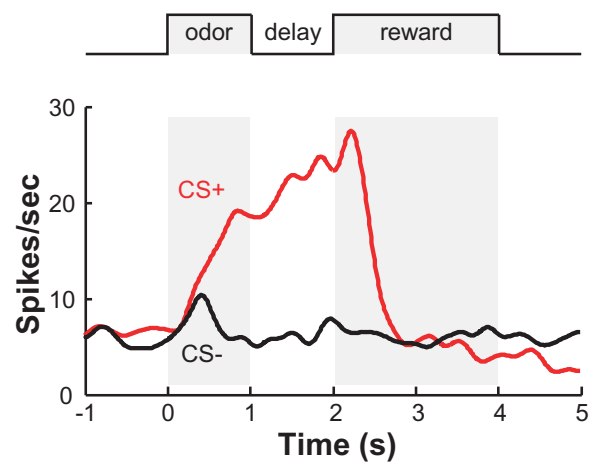

Figure 3. The activity pattern of a DRN Pet-1 neuron from a behaving mouse engaged in a cue-reward association task. Peristimulus time histogram shows the spike firing rate of the DRN Pet- 1 neuron identified with optical tagging. CS + indicates an odorant predicting reward delivery (sucrose). CS - indicates an odorant predicting no sucrose delivery. Adopted from Liu et al. 2014 with permission. 
The imaging and recording studies thus indicate that many DRN neurons, including 5-HT neurons, are activated in various reward-associated tasks. DRN neurons also encode a broad range of sensory, motor, and other task-related variables in rewardseeking behaviors, suggesting that DRN neurons participate in the evaluation and broadcasting of reward-related signals to modulate the forebrain functions related to reinforcement learning and decision making. However, much needs to be done to elucidate the precise activity patterns of the DRN in more reward and punishment-related tasks. Particularly, we need to record the activity of specific types of DRN neurons from freely behaving animals. In addition to classical conditioning, the reward tasks should be expanded to include operant behaviors with precisely controlled parameters of sensory cues, delays, cost, reward values, and reward possibility.

\section{Summary and future directions}

The close involvement of the DRN in reward processing has been repeatedly demonstrated by anatomy, pharmacology, optogenetics, and electrophysiology. Recent optogenetic studies have produced some particularly interesting insights into the contribution of glutamate to the reinforcing potentials of DRN neurons. Moreover, activation of DRN 5-HT neurons promotes patience in delayed reward tasks, suggesting a role of those neurons in reward waiting and compulsivity control.

Many more experiments are required to dissect the exact functions of DRN neurons in reward processing. Reward stimuli can be natural (food and sex) or artificial (drugs or brain stimulation), positive or negative (termination of punishment), and surprising or expected. In addition, reward behaviors consist of multiple psychological processes. Rewards can increase animal motivation ("wanting"), generate the feeling of pleasure ("liking"), and guide the learning process (Berridge et al. 2009). For rewards that are predicted by a sensory cue, the behavioral processes of reward acquisition can be divided into cue detection, anticipation, approaching, waiting, consumption, post-consumption analysis of reward value and cost, and the motivation for pursuit of additional reward. Traditionally, dopamine is considered the synonym of "reward" and dopamine neurons in the VTA has been one of the most thoroughly studied neuron populations for reward processing. Decades of intensive studies have led to the attractive theories that VTA dopamine neurons encode reward prediction error and incentive salience (Schultz et al. 1997; Berridge 2007; Cohen et al. 2012). This suggests that many other reward processes are accomplished by neurons outside the VTA, possibly including neurons in the DRN.

In the last decade, we have witnessed drastic technological developments that promise unparalleled power of probing the functions and mechanisms of neural circuits. We now have numerous animal lines that allow us to specifically target 5-HT, glutamate, GABA, and dopamine neurons in the DRN (Scott et al. 2005; Zhuang et al. 2005; Grimes et al. 2011; Taniguchi et al. 2011; Vong et al. 2011). In light of the overlapping populations of 5-HT and glutamate neurons, additional efforts should be devoted to generating tools that separate neuron subpopulations. Optogenetics and chemogenetics can be applied to activate or inhibit various DRN neuron types in different processes of reward behaviors (Boyden et al. 2005; Fenno et al. 2011; Urban and Roth 2015) Particularly lacking now are the studies that investigate the necessity of DRN neurons by precisely suppressing the activity of specific cell types using optogenetics and chemogenetics (Chuong et al. 2014; Sternson and Roth 2014). The activity patterns can now be examined with optical imaging and optically tagged recordings from freely behaving animals performing re- ward tasks that dissociate various reward processes (Flusberg et al. 2005; Cohen et al. 2012; Hochbaum et al. 2014). Finally, newly developed viral tools and genetic models can be combined to dissect circuit wiring and the molecular signaling pathways in the upstream and downstream stations of the DRN.

The workload may seem daunting, but studies on the DRN and reward should be very rewarding. Rewards are fundamental to animals and humans and the deficits in reward processing are closely linked to many devastating psychiatric disorders. Future discoveries may not only provide a better understanding of the neural mechanisms of animal behavior but also shed lights into novel clinical approaches to treating human diseases.

\section{Acknowledgments}

We thank D. Wang (NIBS) for help with figure preparation. The authors' lab is supported by National Natural Science Foundation of China (91432114), China Ministry of Science and Technology (2012CB837701 \& 2012YQ03026005), and Beijing Municipal Government.

\section{References}

Abellán MT, Jolas T, Aghajanian GK, Artigas F. 2000. Dual control of dorsal raphe serotonergic neurons by GABA(B) receptors. Electrophysiological and microdialysis studies. Synapse 36: 21-34.

Abrams JK, Johnson PL, Hollis JH, Lowry CA. 2004. Anatomic and functional topography of the dorsal raphe nucleus. Ann N Y Acad Sci 1018: $46-57$.

Acevedo BP, Aron A, Fisher HE, Brown LL. 2012. Neural correlates of long-term intense romantic love. Soc Cogn Affect Neurosci 7: 145-159.

Allers KA, Sharp T. 2003. Neurochemical and anatomical identification of fast- and slow-firing neurones in the rat dorsal raphe nucleus using juxtacellular labelling methods in vivo. Neuroscience 122: 193-204.

Angoa-Pérez M, Kane MJ, Briggs DI, Sykes CE, Shah MM, Francescutti DM, Rosenberg DR, Thomas DM, Kuhn DM. 2012. Genetic depletion of brain 5 HT reveals a common molecular pathway mediating compulsivity and impulsivity. J Neurochem 121: 974-984.

Bang SJ, Jensen P, Dymecki SM, Commons KG. 2012. Projections and interconnections of genetically defined serotonin neurons in mice. Eur J Neurosci 35: 85-96.

Bauer CT, Banks ML, Blough BE, Negus SS. 2013. Use of intracranial self-stimulation to evaluate abuse-related and abuse-limiting effects of monoamine releasers in rats. Br J Pharmacol 168: 850-862.

Berridge KC. 2007. The debate over dopamine's role in reward: the case for incentive salience. Psychopharmacology (Berl) 191: 391-431.

Berridge KC, Robinson TE, Aldridge JW. 2009. Dissecting components of reward: 'liking', 'wanting', and learning. Curr Opin Pharmacol 9: 65-73.

Blackburn TP, Minabe Y, Middlemiss DN, Shirayama Y, Hashimoto K, Ashby CR Jr. 2002. Effect of acute and chronic administration of the selective 5-HT2C receptor antagonist SB-243213 on midbrain dopamine neurons in the rat: an in vivo extracellular single cell study. Synapse 46: 129-139.

Boyden ES, Zhang F, Bamberg E, Nagel G, Deisseroth K. 2005. Millisecond-timescale, genetically targeted optical control of neural activity. Nat Neurosci 8: 1263-1268.

Brevard ME, Meyer JS, Harder JA, Ferris CF. 2006. Imaging brain activity in conscious monkeys following oral MDMA ("ecstasy"). Magn Reson Imaging 24: 707-714.

Brigman JL, Mathur P, Harvey-White J, Izquierdo A, Saksida LM, Bussey TJ, Fox S, Deneris E, Murphy DL, Holmes A. 2010. Pharmacological or genetic inactivation of the serotonin transporter improves reversal learning in mice. Cereb Cortex 20: 1955-1963.

Bromberg-Martin ES, Hikosaka O, Nakamura K. 2010. Coding of task reward value in the dorsal raphe nucleus. J Neurosci 30: 6262-6272.

Bubar MJ, Cunningham KA. 2007. Distribution of serotonin 5- $\mathrm{HT}_{2 \mathrm{C}}$ receptors in the ventral tegmental area. Neuroscience 146: 286-297.

Bubar MJ, Stutz SJ, Cunningham KA. 2011. 5- $\mathrm{HT}_{2 \mathrm{C}}$ receptors localize to dopamine and GABA neurons in the rat mesoaccumbens pathway. PLoS One 6: e20508.

Calabresi P, Picconi B, Tozzi A, Di Filippo M. 2007. Dopamine-mediated regulation of corticostriatal synaptic plasticity. Trends Neurosci 30: 211-219.

Calizo LH, Akanwa A, Ma X, Pan YZ, Lemos JC, Craige C, Heemstra L, Beck SG. 2011. Raphe serotonin neurons are not homogenous: electrophysiological, morphological and neurochemical evidence. Neuropharmacology 61: 524-543. 
Carroll ME, Lac ST, Asencio M, Kragh R. 1990. Fluoxetine reduces intravenous cocaine self-administration in rats. Pharmacol Biochem Behav 35: 237-244.

Challis C, Boulden J, Veerakumar A, Espallergues J, Vassoler FM, Pierce RC, Beck SG, Berton O. 2013. Raphe GABAergic neurons mediate the acquisition of avoidance after social defeat. J Neurosci 33: 13978-13988, 13988a.

Chen NH, Reith ME. 1995. Monoamine interactions measured by microdialysis in the ventral tegmental area of rats treated systemically with ( \pm ) - 8-hydroxy-2-(di-n-propylamino) tetralin. J Neurochem 64: $1585-1597$.

Chuong AS, Miri ML, Busskamp V, Matthews GA, Acker LC, Sørensen AT, Young A, Klapoetke NC, Henninger MA, Kodandaramaiah SB, et al. 2014. Noninvasive optical inhibition with a red-shifted microbial rhodopsin. Nat Neurosci 17: 1123-1129.

Clarke HF, Dalley JW, Crofts HS, Robbins TW, Roberts AC. 2004. Cognitive inflexibility after prefrontal serotonin depletion. Science 304: 878-880.

Cohen JY, Haesler S, Vong L, Lowell BB, Uchida N. 2012. Neuron-type-specific signals for reward and punishment in the ventral tegmental area. Nature 482: $85-88$.

Cohen JY, Amoroso MW, Uchida N. 2015. Serotonergic neurons signal reward and punishment on multiple timescales. Elife:doi: 10.7554/ eLife.06346.

Commons KG. 2009. Locally collateralizing glutamate neurons in the dorsal raphe nucleus responsive to substance P contain vesicular glutamate transporter 3 (VGLUT3). I Chem Neuroanat 38: 273-281.

Corbett D, Wise RA. 1979. Intracranial self-stimulation in relation to the ascending noradrenergic fiber systems of the pontine tegmentum and caudal midbrain: a moveable electrode mapping study. Brain Res 177: $423-436$.

Cunningham KA, Fox RG, Anastasio NC, Bubar MJ, Stutz SJ, Moeller FG, Gilbertson SR, Rosenzweig-Lipson S. 2011. Selective serotonin 5-HT $2 \mathrm{C}$ receptor activation suppresses the reinforcing efficacy of cocaine and sucrose but differentially affects the incentive-salience value of cocaine vs. sucrose-associated cues. Neuropharmacology 61: 513-523.

Daw ND, Touretzky DS. 2002. Long-term reward prediction in TD models of the dopamine system. Neural Comput 14: 2567-2583.

Daw ND, Kakade S, Dayan P. 2002. Opponent interactions between serotonin and dopamine. Neural Netw 15: 603-616.

Dayan P, Balleine BW. 2002. Reward, motivation, and reinforcement learning. Neuron 36: 285-298.

Dayan P, Huys QJ. 2009. Serotonin in affective control. Annu Rev Neurosci 32: $95-126$.

Deakin JF, Graeff FG. 1991. 5-HT and mechanisms of defence. J Psychopharmacol 5: 305-315.

Der-Avakian A, Markou A. 2012. The neurobiology of anhedonia and other reward-related deficits. Trends Neurosci 35: 68-77.

Descarries L, Berthelet F, Garcia S, Beaudet A. 1986. Dopaminergic projection from nucleus raphe dorsalis to neostriatum in the rat. J Comp Neurol 249: 511-520.

Di Giovanni G, Esposito E, Di Matteo V. 2010. Role of serotonin in central dopamine dysfunction. CNS Neurosci Ther 16: 179-194.

Dorocic IP, Fürth D, Xuan Y, Johansson Y, Pozzi L, Silberberg G, Carlén M, Meletis K. 2014. A whole-brain atlas of inputs to serotonergic neurons of the dorsal and median raphe nuclei. Neuron 83: 663-678.

Dougalis AG, Matthews GA, Bishop MW, Brischoux F, Kobayashi K, Ungless MA. 2012. Functional properties of dopamine neurons and co-expression of vasoactive intestinal polypeptide in the dorsal raphe nucleus and ventro-lateral periaqueductal gray. Eur J Neurosci 36: 3322-3332.

Fenno L, Yizhar O, Deisseroth K. 2011. The development and application of optogenetics. Annu Rev Neurosci 34: 389-412.

Ferris CF, Snowdon CT, King JA, Sullivan JM Jr, Ziegler TE, Olson DP, Schultz-Darken NJ, Tannenbaum PL, Ludwig R, Wu Z. 2004. Activation of neural pathways associated with sexual arousal in non-human primates. J Magn Reson Imaging 19: 168-175.

Fischer AG, Jocham G, Ullsperger M. 2015. Dual serotonergic signals: a key to understanding paradoxical effects? Trends Cogn Sci 19: 21-26.

Fletcher PJ. 1996. Injection of 5-HT into the nucleus accumbens reduces the effects of d-amphetamine on responding for conditioned reward. Psychopharmacology 126: 62-69.

Fletcher PJ, Korth KM. 1999. Activation of 5-HT1B receptors in the nucleus accumbens reduces amphetamine-induced enhancement of responding for conditioned reward. Psychopharmacology (Berl) 142: 165-174.

Fletcher PJ, Ming ZH, Higgins GA. 1993. Conditioned place preference induced by microinjection of 8 -OH-DPAT into the dorsal or median raphe nucleus. Psychopharmacology (Berl) 113: 31-36.

Fletcher PJ, Korth KM, Chambers JW. 1999. Selective destruction of brain serotonin neurons by 5,7-dihydroxytryptamine increases responding for a conditioned reward. Psychopharmacology (Berl) 147: 291-299.
Fletcher PJ, Azampanah A, Korth KM. 2002. Activation of 5-HT(1B) receptors in the nucleus accumbens reduces self-administration of amphetamine on a progressive ratio schedule. Pharmacol Biochem Behav 71: $717-725$.

Flores JA, El Banoua F, Galán-Rodríguez B, Fernandez-Espejo E. 2004. Opiate anti-nociception is attenuated following lesion of large dopamine neurons of the periaqueductal gray: critical role for D1 (not D2) dopamine receptors. Pain 110: 205-214.

Flusberg BA, Cocker ED, Piyawattanametha W, Jung JC, Cheung ELM, Schnitzer MJ. 2005. Fiber-optic fluorescence imaging. Nat Methods 2: 941-950.

Fonseca MS, Murakami M, Mainen ZF. 2015. Activation of dorsal raphe serotonergic neurons promotes waiting but is not reinforcing. Curr Biol 25: 306-315.

Fornal CA, Metzler CW, Marrosu F, Jacobs BL. 1996. A subgroup of dorsal raphe serotonergic neurons in the cat is strongly activated during oral-buccal movements. Brain Res 716: $123-133$.

Fremeau RT, Burman J, Qureshi T, Tran CH, Proctor J, Johnson J, Zhang H, Sulzer D, Copenhagen DR, Storm-Mathisen J. 2002. The identification of vesicular glutamate transporter 3 suggests novel modes of signaling by glutamate. Proc Natl Acad Sci 99: 14488-14493.

Fu W, Le Maître E, Fabre V, Bernard JF, David Xu ZQ, Hökfelt T. 2010. Chemical neuroanatomy of the dorsal raphe nucleus and adjacent structures of the mouse brain. J Comp Neurol 518: 3464-3494.

Gartside SE, McQuade R, Sharp T. 1997. Acute effects of 3,4-methylenedioxymethamphetamine (MDMA) on 5-HT cell firing and release: comparison between dorsal and median raphe 5-HT systems. Neuropharmacology 36: 1697-1703.

Gong S, Doughty M, Harbaugh CR, Cummins A, Hatten ME, Heintz N, Gerfen CR. 2007. Targeting Cre recombinase to specific neuron populations with bacterial artificial chromosome constructs. J Neurosci 27: $9817-9823$.

Gras C, Herzog E, Bellenchi GC, Bernard V, Ravassard P, Pohl M, Gasnier B, Giros B, El Mestikawy S. 2002. A third vesicular glutamate transporter expressed by cholinergic and serotoninergic neurons. J Neurosci 22: $5442-5451$.

Green AR. 2006. Neuropharmacology of 5-hydroxytryptamine. $\mathrm{Br} J$ Pharmacol 147 Suppl 1: 145-152.

Grimes WN, Seal RP, Oesch N, Edwards RH, Diamond JS. 2011. Genetic targeting and physiological features of VGLUT3+ amacrine cells. Vis Neurosci 28: 381-392.

Gutknecht L, Popp S, Waider J, Sommerlandt FM, Göppner C, Post A, Reif A, van den Hove D, Strekalova T, Schmitt A, et al. 2015. Interaction of brain 5-HT synthesis deficiency, chronic stress and sex differentially impact emotional behavior in Tph2 knockout mice. Psychopharmacology (Berl) 232: 2429-2441.

Hajós M, Allers KA, Jennings K, Sharp T, Charette G, Sík A, Kocsis B. 2007. Neurochemical identification of stereotypic burst-firing neurons in the rat dorsal raphe nucleus using juxtacellular labelling methods. Eur J Neurosci 25: 119-126.

Harrison AA, Everitt BJ, Robbins TW. 1997. Central 5-HT depletion enhances impulsive responding without affecting the accuracy of attentional performance: interactions with dopaminergic mechanisms. Psychopharmacology (Berl) 133: 329-342.

Hashimoto S, Inoue T, Koyama T. 1996. Serotonin reuptake inhibitors reduce conditioned fear stress-induced freezing behavior in rats. Psychopharmacology 123: 182-186.

Hayashi K, Nakao K, Nakamura K. 2015. Appetitive and aversive information coding in the primate dorsal raphé nucleus. J Neurosci 35: 6195-6208.

Hayes DJ, Greenshaw AJ. 2011. 5-HT receptors and reward-related behaviour: a review. Neurosci Biobehav Rev 35: 1419-1449.

Herzog E, Gilchrist J, Gras C, Muzerelle A, Ravassard P, Giros B, Gaspar P, El Mestikawy S. 2004. Localization of VGLUT3, the vesicular glutamate transporter type 3, in the rat brain. Neuroscience 123: 983-1002.

Higgins GA, Fletcher PJ. 2003. Serotonin and drug reward: focus on 5-HT receptors. Eur J Pharmacol 480: 151-162.

Hioki H, Nakamura H, Ma YF, Konno M, Hayakawa T, Nakamura KC, Fujiyama F, Kaneko T. 2010. Vesicular glutamate transporter 3-expressing nonserotonergic projection neurons constitute a subregion in the rat midbrain raphe nuclei. J Comp Neurol 518: $668-686$.

Hirschfeld RM. 2000. History and evolution of the monoamine hypothesis of depression. J Clin Psychiatry 61 Suppl 6: 4-6.

Hnasko TS, Sotak BN, Palmiter RD. 2007. Cocaine-conditioned place preference by dopamine-deficient mice is mediated by serotonin. $J$ Neurosci 27: 12484-12488.

Hochbaum DR, Zhao Y, Farhi SL, Klapoetke N, Werley CA, Kapoor V, Zou P, Kralj JM, Maclaurin D, Smedemark-Margulies N, et al. 2014. All-optical electrophysiology in mammalian neurons using engineered microbial rhodopsins. Nat Methods 11: 825-833. 
Hökfelt T, Arvidsson U, Cullheim S, Millhorn D, Nicholas AP, Pieribone V, Seroogy K, Ulfhake B. 2000. Multiple messengers in descending serotonin neurons: localization and functional implications. J Chem Neuroanat 18: 75-86.

Inaba K, Mizuhiki T, Setogawa T, Toda K, Richmond BJ, Shidara M. 2013. Neurons in monkey dorsal raphe nucleus code beginning and progress of step-by-step schedule, reward expectation, and amount of reward outcome in the reward schedule task. J Neurosci 33: 3477-3491.

Ishimura K, Takeuchi Y, Fujiwara K, Tominaga M, Yoshioka H, Sawada T. 1988. Quantitative analysis of the distribution of serotonin-immunoreactive cell bodies in the mouse brain. Neurosci Lett 91: $265-270$.

Izquierdo A, Carlos K, Ostrander S, Rodriguez D, McCall-Craddolph A, Yagnik G, Zhou F. 2012. Impaired reward learning and intact motivation after serotonin depletion in rats. Behav Brain Res 233: 494-499.

Jackson J, Bland BH, Antle MC. 2009. Nonserotonergic projection neurons in the midbrain raphe nuclei contain the vesicular glutamate transporter VGLUT3. Synapse 63: 31-41.

Kane MJ, Angoa-Peréz M, Briggs DI, Sykes CE, Francescutti DM, Rosenberg DR, Kuhn DM. 2012. Mice genetically depleted of brain serotonin display social impairments, communication deficits and repetitive behaviors: possible relevance to autism. PLoS One 7: e48975.

Katsidoni V, Apazoglou K, Panagis G. 2011. Role of serotonin 5-HT2A and 5 -HT2C receptors on brain stimulation reward and the reward-facilitating effect of cocaine. Psychopharmacology (Berl) 213: $337-354$.

Kirby LG, Pernar L, Valentino RJ, Beck SG. 2003. Distinguishing characteristics of serotonin and non-serotonin-containing cells in the dorsal raphe nucleus: electrophysiological and immunohistochemical studies. Neuroscience 116: 669-683.

Kiyasova V, Fernandez SP, Laine J, Stankovski L, Muzerelle A, Doly S, Gaspar P. 2011. A genetically defined morphologically and functionally unique subset of 5-HT neurons in the mouse raphe nuclei. J Neurosci 31: $2756-2768$.

Kranz GS, Kasper S, Lanzenberger R. 2010. Reward and the serotonergic system. Neuroscience 166: 1023-1035.

Lammel S, Lim BK, Ran C, Huang KW, Betley MJ, Tye KM, Deisseroth K, Malenka RC. 2012. Input-specific control of reward and aversion in the ventral tegmental area. Nature 491: 212-217.

Leccese AP, Lyness WH. 1984. The effects of putative 5-hydroxytryptamine receptor active agents on D-amphetamine self-administration in controls and rats with 5,7-dihydroxytryptamine median forebrain bundle lesion. Brain Res 303: 153-162.

Lesch KP, Waider J. 2012. Serotonin in the modulation of neural plasticity and networks: implications for neurodevelopmental disorders. Neuron 76: $175-191$

Li Y, Dalphin N, Hyland BI. 2013. Association with reward negatively modulates short latency phasic conditioned responses of dorsal raphe nucleus neurons in freely moving rats. J Neurosci 33: 5065-5078.

Liechti ME, Vollenweider FX. 2001. Which neuroreceptors mediate the subjective effects of MDMA in humans? A summary of mechanistic studies. Hum Psychopharmacol 16: 589-598.

Liu ZH, Ikemoto S. 2007. The midbrain raphe nuclei mediate primary reinforcement via GABA(A) receptors. Eur J Neurosci 25: 735-743.

Liu R, Jolas T, Aghajanian G. 2000. Serotonin 5- $\mathrm{HT}_{2}$ receptors activate local GABA inhibitory inputs to serotonergic neurons of the dorsal raphe nucleus. Brain Res 873: 34-45.

Liu Y, Jiang Y, Si Y, Kim JY, Chen ZF, Rao Y. 2011. Molecular regulation of sexual preference revealed by genetic studies of 5-HT in the brains of male mice. Nature 472: 95-99.

Liu Z, Zhou J, Li Y, Hu F, Lu Y, Ma M, Feng Q, Zhang JE, Wang D, Zeng J, et al. 2014. Dorsal raphe neurons signal reward through 5-HT and glutamate. Neuron 81: 1360-1374.

Macoveanu J. 2014. Serotonergic modulation of reward and punishment: evidence from pharmacological fMRI studies. Brain Res 1556: 19-27.

Matsumoto M, Togashi H, Mori K, Ueno K, Miyamoto A, Yoshioka M. 1999. Characterization of endogenous serotonin-mediated regulation of dopamine release in the rat prefrontal cortex. Eur J Pharmacol 383: $39-48$.

McDannald MA. 2015. Serotonin: waiting but not rewarding. Curr Biol 25: R103-R104.

McDevitt RA, Tiran-Cappello A, Shen H, Balderas I, Britt JP, Marino RA, Chung SL, Richie CT, Harvey BK, Bonci A. 2014. Serotonergic versus nonserotonergic dorsal raphe projection neurons: differential participation in reward circuitry. Cell Rep 8: 1857-1869.

McGinty DJ, Harper RM. 1976. Dorsal raphe neurons: depression of firing during sleep in cats. Brain Res 101: 569-575.

McGregor A, Lacosta S, Roberts D. 1993. L-tryptophan decreases the breaking point under a progressive ratio schedule of intravenous cocaine reinforcement in the rat. Pharmacol Biochem Behav 44: $651-655$.
Minabe Y, Emori K, Ashby CR. 1996. The depletion of brain serotonin levels by para-chlorophenylalanine administration significantly alters the activity of midbrain dopamine cells in rats: an extracellular single cell recording study. Synapse 22: 46-53.

Minabe Y, Hashimoto K, Watanabe KI, Ashby CR Jr. 2001. Acute and repeated administration of the selective 5-HT2A receptor antagonist M100907 significantly alters the activity of midbrain dopamine neurons: an in vivo electrophysiological study. Synapse 40: 102-112.

Miyazaki K, Miyazaki KW, Doya K. 2011a. Activation of dorsal raphe serotonin neurons underlies waiting for delayed rewards. J Neurosci 31: 469-479.

Miyazaki KW, Miyazaki K, Doya K. 2011b. Activation of the central serotonergic system in response to delayed but not omitted rewards. Eur I Neurosci 33: 153-160.

Miyazaki K, Miyazaki KW, Doya K. 2012a. The role of serotonin in the regulation of patience and impulsivity. Mol Neurobiol 45: 213-224.

Miyazaki KW, Miyazaki K, Doya K. 2012b. Activation of dorsal raphe serotonin neurons is necessary for waiting for delayed rewards. $J$ Neurosci 32: 10451-10457.

Miyazaki KW, Miyazaki K, Tanaka KF, Yamanaka A, Takahashi A, Tabuchi S, Doya K. 2014. Optogenetic activation of dorsal raphe serotonin neurons enhances patience for future rewards. Curr Biol 24: 2033-2040.

Nakamura K. 2013. The role of the dorsal raphé nucleus in reward-seeking behavior. Front Integr Neurosci 7: 60

Nakamura K, Matsumoto M, Hikosaka O. 2008. Reward-dependent modulation of neuronal activity in the primate dorsal raphe nucleus. $J$ Neurosci 28: 5331-5343.

Nonkes LJ, Homberg JR. 2013. Perseverative instrumental and Pavlovian responding to conditioned stimuli in serotonin transporter knockout rats. Neurobiol Learn Mem 100: 48-55.

Nonkes LJ, Tomson K, Maertin A, Dederen J, Maes JH, Homberg J. 2010. Orbitofrontal cortex and amygdalar over-activity is associated with an inability to use the value of expected outcomes to guide behaviour in serotonin transporter knockout rats. Neurobiol Learn Mem 94: 65-72.

Ogawa SK, Cohen JY, Hwang D, Uchida N, Watabe-Uchida M. 2014. Organization of monosynaptic inputs to the serotonin and dopamine neuromodulatory systems. Cell Rep 8: 1105-1118.

Ohmura Y, Tanaka KF, Tsunematsu T, Yamanaka A, Yoshioka M. 2014. Optogenetic activation of serotonergic neurons enhances anxiety-like behaviour in mice. Int J Neuropsychoph 17: 1777-1783.

Olds J, Milner P. 1954. Positive reinforcement produced by electrical stimulation of septal area and other regions of rat brain. QJ Exp Psychol 47: 419 .

Orosco M, Rouch C, Beslot F, Feurte S, Regnault A, Dauge V. 2004. $\alpha$-Lactalbumin-enriched diets enhance serotonin release and induce anxiolytic and rewarding effects in the rat. Behav Brain Res 148: 1-10.

Owens MJ, Nemeroff CB. 1994. Role of serotonin in the pathophysiology of depression: focus on the serotonin transporter. Clin Chem 40: 288-295.

Pedroni A, Koeneke S, Velickaite A, Jäncke L. 2011. Differential magnitude coding of gains and omitted rewards in the ventral striatum. Brain Res 1411: $76-86$.

Peltier R, Schenk S. 1993. Effects of serotonergic manipulations on cocaine self-administration in rats. Psychopharmacology (Berl) 110: 390-394

Peyron C, Petit JM, Rampon C, Jouvet M, Luppi PH. 1998. Forebrain afferents to the rat dorsal raphe nucleus demonstrated by retrograde and anterograde tracing methods. Neuroscience 82: 443-468.

Prisco S, Pagannone S, Esposito E. 1994. Serotonin-dopamine interaction in the rat ventral tegmental area: an electrophysiological study in vivo. $J$ Pharmacol Exp Ther 271: 83-90.

Przegaliński E, Gołda A, Frankowska M, Zaniewska M, Filip M. 2007. Effects of serotonin 5-HT1B receptor ligands on the cocaine- and food-maintained self-administration in rats. Eur J Pharmacol 559: $165-172$

Qi J, Zhang S, Wang HL, Wang H, Buendia JdJA, Hoffman AF, Lupica CR, Seal RP, Morales M. 2014. A glutamatergic reward input from the dorsal raphe to ventral tegmental area dopamine neurons. Nat Commun 5: 5390.

Ranade SP, Mainen ZF. 2009. Transient firing of dorsal raphe neurons encodes diverse and specific sensory, motor, and reward events. J Neurophysiol 102: 3026-3037.

Ranade S, Pi HJ, Kepecs A. 2014. Neuroscience: waiting for serotonin. Curr Biol 24: R803-R805.

Redgrave P. 1978. Modulation of intracranial self-stimulation behaviour by local perfusions of dopamine, noradrenaline and serotonin within the caudate nucleus and nucleus accumbens. Brain Res 155: 277-295.

Redgrave P, Horrell RI. 1976. Potentiation of central reward by localised perfusion of acetylcholine and 5-hydroxytryptamine. Nature 262: 305-307.

Rocha BA, Scearce-Levie K, Lucas JJ, Hiroi N, Castanon N, Crabbe JC, Nestler EJ, Hen R. 1998. Increased vulnerability to cocaine in mice lacking the serotonin-1B receptor. Nature 393: 175-178. 
Rompre PP, Miliaressis E. 1985. Pontine and mesencephalic substrates of self-stimulation. Brain Res 359: 246-259.

Sakai K, Crochet S. 2001. Differentiation of presumed serotonergic dorsal raphe neurons in relation to behavior and wake-sleep states. Neuroscience 104: 1141-1155.

Sanders AC, Hussain AJ, Hen R, Zhuang X. 2007. Chronic blockade or constitutive deletion of the serotonin transporter reduces operant responding for food reward. Neuropsychopharmacology 32: 2321-2329.

Sasaki-Adams DM, Kelley AE. 2001. Serotonin-dopamine interactions in the control of conditioned reinforcement and motor behavior. Neuropsychopharmacology 25: 440-452.

Savelieva KV, Zhao S, Pogorelov VM, Rajan I, Yang Q, Cullinan E, Lanthorn TH. 2008. Genetic disruption of both tryptophan hydroxylase genes dramatically reduces serotonin and affects behavior in models sensitive to antidepressants. PLoS One 3: e3301.

Savitz J, Lucki I, Drevets WC. 2009. 5-HT(1A) receptor function in major depressive disorder. Prog Neurobiol 88: 17-31.

Schäfer MK, Varoqui H, Defamie N, Weihe E, Erickson JD. 2002. Molecular cloning and functional identification of mouse vesicular glutamate transporter 3 and its expression in subsets of novel excitatory neurons. Biol Chem 277: 50734-50748.

Schultz W, Dayan P, Montague PR. 1997. A neural substrate of prediction and reward. Science 275: 1593-1599.

Schweimer JV, Ungless MA. 2010. Phasic responses in dorsal raphe serotonin neurons to noxious stimuli. Neuroscience 171: 1209-1215.

Schweimer JV, Mallet N, Sharp T, Ungless MA. 2011. Spike-timing relationship of neurochemically-identified dorsal raphe neurons during cortical slow oscillations. Neuroscience 196: 115-123.

Scott MM, Wylie CJ, Lerch JK, Murphy R, Lobur K, Herlitze S, Jiang W, Conlon RA, Strowbridge BW, Deneris ES. 2005. A genetic approach to access serotonin neurons for in vivo and in vitro studies. Proc Natl Acad Sci 102: 16472-16477.

Seymour B, Daw ND, Roiser JP, Dayan P, Dolan R. 2012. Serotonin selectively modulates reward value in human decision-making. $J$ Neurosci 32: 5833-5842.

Shin R, Ikemoto S. 2010. The GABAB receptor agonist baclofen administered into the median and dorsal raphe nuclei is rewarding as shown by intracranial self-administration and conditioned place preference in rats. Psychopharmacology (Berl) 208: 545-554.

Shutoh F, Ina A, Yoshida S, Konno J, Hisano S. 2008. Two distinct subtypes of serotonergic fibers classified by co-expression with vesicular glutamate transporter 3 in rat forebrain. Neurosci Lett 432: 132-136.

Simon H, Le Moal M, Cardo B. 1976. Intracranial self-stimulation from the dorsal raphe nucleus of the rat: effects of the injection of para-chlorophenylalanine and of $\alpha$-methylparatyrosine. Behav Biol 16: $353-364$.

Smith FL, Yu DS, Smith DG, Leccese AP, Lyness WH. 1986. Dietary tryptophan supplements attenuate amphetamine self-administration in the rat. Pharmacol Biochem Behav 25: 849-855.

Sora I, Wichems C, Takahashi N, Li X-F, Zeng Z, Revay R, Lesch K-P, Murphy DL, Uhl GR. 1998. Cocaine reward models: conditioned place preference can be established in dopamine- and in serotonin-transporter knockout mice. Proc Natl Acad Sci 95: 7699-7704.

Sora I, Hall FS, Andrews AM, Itokawa M, Li XF, Wei HB, Wichems C, Lesch KP, Murphy DL, Uhl GR. 2001. Molecular mechanisms of cocaine reward: combined dopamine and serotonin transporter knockouts eliminate cocaine place preference. Proc Natl Acad Sci 98: 5300-5305.

Soubrie P, Martin P, el Mestikawy S, Thiebot MH, Simon P, Hamon M. 1986. The lesion of serotonergic neurons does not prevent antidepressant-induced reversal of escape failures produced by inescapable shocks in rats. Pharmacol Biochem Behav 25: 1-6.
Sternson SM, Roth BL. 2014. Chemogenetic tools to interrogate brain functions. Annu Rev Neurosci 37: 387-407.

Stratford TR, Wirtshafter D. 1990. Ascending dopaminergic projections from the dorsal raphe nucleus in the rat. Brain Res 511: 173-176.

Suzuki Y, Kiyokage E, Sohn J, Hioki H, Toida K. 2015. Structural basis for serotonergic regulation of neural circuits in the mouse olfactory bulb. $J$ Comp Neurol 523: 262-280.

Tanaka SC, Doya K, Okada G, Ueda K, Okamoto Y, Yamawaki S. 2004. Prediction of immediate and future rewards differentially recruits cortico-basal ganglia loops. Nat Neurosci 7: 887-893.

Taniguchi H, He M, Wu P, Kim S, Paik R, Sugino K, Kvitsiani D, Fu Y, Lu J, Lin Y, et al. 2011. A resource of Cre driver lines for genetic targeting of GABAergic neurons in cerebral cortex. Neuron 71: 995-1013.

Tao R, Ma Z, Auerbach SB. 1996. Differential regulation of 5-hydroxytryptamine release by GABAA and GABAB receptors in midbrain raphe nuclei and forebrain of rats. Br J Pharmacol 119: $1375-1384$

Tye NC, Everitt BJ, Iversen SD. 1977. 5-Hydroxytryptamine and punishment. Nature 268: 741-743.

Urban DJ, Roth BL. 2015. DREADDs (designer receptors exclusively activated by designer drugs): chemogenetic tools with therapeutic utility. Annu Rev Pharmacol Toxicol 55: 399-417.

Van Der Kooy D, Fibiger HC, Phillips AG. 1978. An analysis of dorsal and median raphe self-stimulation: effects of parachlorophenylalanine. Pharmacol Biochem Behav 8: 441-445.

Vong L, Ye C, Yang Z, Choi B, Chua S Jr, Lowell BB. 2011. Leptin action on GABAergic neurons prevents obesity and reduces inhibitory tone to POMC neurons. Neuron 71: 142-154.

Walther DJ, Peter JU, Bashammakh S, Hörtnagl H, Voits M, Fink H, Bader M. 2003. Synthesis of serotonin by a second tryptophan hydroxylase isoform. Science 299: 76.

Waterhouse BD, Devilbiss D, Seiple S, Markowitz R. 2004. Sensorimotor-related discharge of simultaneously recorded, single neurons in the dorsal raphe nucleus of the awake, unrestrained rat. Brain Res 1000: 183-191.

Weissbourd B, Ren J, DeLoach KE, Guenthner CJ, Miyamichi K, Luo L. 2014. Presynaptic partners of dorsal raphe serotonergic and GABAergic neurons. Neuron 83: 645-662.

Winstanley CA, Theobald DE, Dalley JW, Glennon JC, Robbins TW. 2004. 5-HT2A and 5-HT2C receptor antagonists have opposing effects on a measure of impulsivity: interactions with global 5-HT depletion. Psychopharmacology (Berl) 176: 376-385.

Wu Q, Clark MS, Palmiter RD. 2012. Deciphering a neuronal circuit that mediates appetite. Nature 483: 594-597.

Yoshida M, Shirouzu M, Tanaka M, Semba K, Fibiger H. 1989. Dopaminergic neurons in the nucleus raphe dorsalis innervate the prefrontal cortex in the rat: a combined retrograde tracing and immunohistochemical study using anti-dopamine serum. Brain Res 496: $373-376$.

Zhang S, Liu Y, Rao Y. 2013. Serotonin signaling in the brain of adult female mice is required for sexual preference. Proc Natl Acad Sci 110: 9968-9973.

Zhou J, Jia C, Feng Q, Bao J, Luo M. 2015. Prospective coding of dorsal raphe reward signals by the orbitofrontal cortex. J Neurosci 35: 2717-2730.

Zhuang X, Masson J, Gingrich JA, Rayport S, Hen R. 2005. Targeted gene expression in dopamine and serotonin neurons of the mouse brain. $J$ Neurosci Methods 143: 27-32.

Received March 19, 2015; accepted in revised form July 6, 2015. 


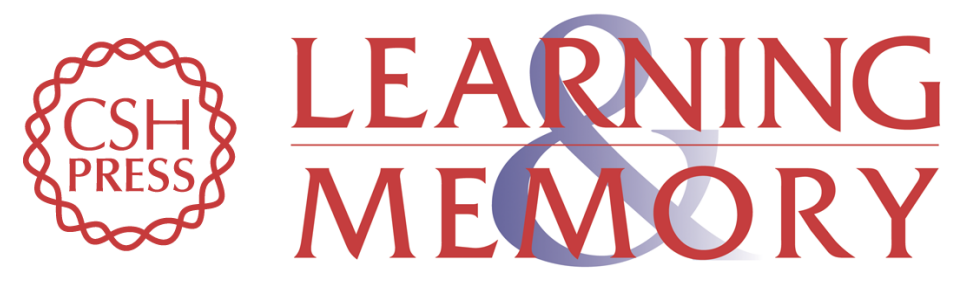

\section{Reward processing by the dorsal raphe nucleus: 5-HT and beyond}

Minmin Luo, Jingfeng Zhou and Zhixiang Liu

Learn. Mem. 2015, 22:

Access the most recent version at doi:10.1101//m.037317.114

References This article cites 159 articles, 25 of which can be accessed free at: http://learnmem.cshlp.org/content/22/9/452.full.html\#ref-list-1

Creative This article is distributed exclusively by Cold Spring Harbor Laboratory Press for the Commons first 12 months after the full-issue publication date (see

License http://learnmem.cshlp.org/site/misc/terms.xhtml). After 12 months, it is available under a Creative Commons License (Attribution-NonCommercial 4.0 International), as described at http://creativecommons.org/licenses/by-nc/4.0/.

Email Alerting Receive free email alerts when new articles cite this article - sign up in the box at the Service top right corner of the article or click here. 